EMBRYARIDDLE
Aeronautical University

SCHOLARLY COMMONS
International Journal of Aviation, Aeronautics, and Aerospace

\title{
Hazards and Mitigation Measures in Aerospace Non-Destructive Testing
}

Khay-Wai Leong

Embry-Riddle Aeronautical University, leongk2@my.erau.edu

Patti J. Clark

Embry-Riddle Aeronautical University, clark092@erau.edu

Follow this and additional works at: https://commons.erau.edu/ijaaa

Part of the Health and Medical Administration Commons, and the Maintenance Technology Commons

\section{Scholarly Commons Citation}

Leong, K., \& Clark, P. J. (2018). Hazards and Mitigation Measures in Aerospace Non-Destructive Testing. International Journal of Aviation, Aeronautics, and Aerospace, 5(1). https://doi.org/10.15394/

ijaaa.2018.1196

This Literature Review is brought to you for free and open access by the Journals at Scholarly Commons. It has been accepted for inclusion in International Journal of Aviation, Aeronautics, and Aerospace by an authorized administrator of Scholarly Commons. For more information, please contact commons@erau.edu. 
Hazards and Mitigation Measures in Aerospace Non-Destructive Testing

Cover Page Footnote

The authors would like to thank the reviewers for their thoughtful comments and suggested improvements. 
Many aircraft components are subject to tensile/torsional/bending forces and heat cycles during operation. As a result, aviation regulatory authorities and component manufacturers have mandated non-destructive inspection programs via airworthiness directives, advisories, and maintenance manuals (Federal Aviation Administration, 1998) to ensure the detection of cracks and flaws on the aircraft structure, engine, and other components prior to catastrophic failure. Examples of non-destructive inspection methods include eddy current, magnetic particle, dye penetrant, radiography, ultrasound, and infrared thermography. Utilizing eddy current, magnetic particle, dye penetrant and radiography testing methods can expose workers to harmful substances and procedures, and these substances and procedures are known to affect the health of the workers involved. The following section elaborates on the hazards and their mechanisms of action. The Risk Mitigation section proposes various engineering, work practices, housekeeping, and personal protection controls required to minimize worker exposure to these hazards.

\section{Hazards}

Magnetic particles and dye penetrant inspection are two standard methods used for detecting surface breaking defects, while eddy current inspection is used to detect cracks or corrosion on back metallic surfaces, or cracks in the underlying structure (Ansley, Bakanas, Castronuovo, Grant, \& Vichi, 1992). In magnetic particle inspection, a ferromagnetic surface is first cleaned and demagnetized. Magnetic particles are then spread in dry powder or in a liquid suspension. The component is then magnetized, and the magnetic particles form around discontinuities on the surface or subsurface. In dye penetrant inspection, a liquid dye and developer are either painted or sprayed on the surface. The dye and developer penetrate cracks on the component surface. The component is then inspected under visible or fluorescent light, depending on the type of dye. Eddy current instrumentation utilizes an alternating current electric coil-generated magnetic field to induce eddy currents in the component being examined. Typical electromagnetic field $(\mathrm{EMF})$ penetration frequencies in eddy current testing range from $100 \mathrm{~Hz}$ to $10 \mathrm{MHz}$ (Ansley et al., 1992; García-Martín, Gómez-Gil, \& Vázquez-Sánchez, 2011), although García-Martín et al. reported inspection frequencies of up to $25 \mathrm{MHz}$. Lippert et al. (2007) found that workers at a turbine engine overhaul and repair center had recorded electromagnetic flux densities as high as $29.27 \mathrm{mT}$ while carrying out magnetic particle inspection using a 3-phase 1400-5000 A $60 \mathrm{~Hz}$ alternating current system. However, the World Health Organization (n.d.) recommends that workers not be exposed to EMF levels above $500 \mu \mathrm{T}$ at the $50 / 60 \mathrm{~Hz}$ line frequency. Additionally, the Electric Power Research Institute (2003) recommended that companies adhere to the Institute of Electrical and Electronics Engineers (IEEE) Standard for occupational maximum EMF 
exposure level of $2.71 \mathrm{mT}$ at $60 \mathrm{~Hz}$. Failure to follow the guidelines may cause workers to suffer from the following short-term effects:

- Aversive or painful stimulation of sensory or motor neurons.

- Muscle excitation that may lead to injury while performing hazardous activities.

- Excitation of neurons or direct alteration of synaptic activity within the brain.

- Cardiac excitation.

- Adverse effects associated with induced potentials or forces on rapidly moving ions with the body, such as blood flow.

Golka et al. (2012) found nine patients and Noon, Pickvance, and Catto (2012) discovered eight patients who had contracted bladder cancer through chronic exposure to dye chemicals. Azo dyes are known to undergo reductive metabolism in the gastrointestinal tract, releasing various aromatic amines. This results in an increased risk for urothelial cell carcinoma. Naphthalimide and naphthalazine-based chemicals have also been identified as possible carcinogens. These dye chemicals can enter the human body through inhalation (chemical in aerosol) or direct contact (chemical solution on skin seeps into subcutaneous tissue). Although the European Union (EU) restricted the use of aromatic amine dye, azo dye-based spray penetrants are still available. Additionally, the United Kingdom Health and Safety Executive (UK HSE) estimated that 55,000 cans of red azo dye had been used in 2007, and up to 200,000 workers may have been exposed to the dye chemical (Noon et al., 2012).

Radiographic inspection involves transmitting ionizing electromagnetic waves in the form of X-rays or gamma-rays into the aircraft component material and using film or electronic devices to capture the differences in wave energy absorbed by the component, depending on component thickness or density (Ansley et al., 1992). The American Cancer Society (2015) describes both short and longterm effects of $\mathrm{X}$-ray and gamma-ray radiation as follows:

If ionizing radiation passes through a cell in the body, it can lead to mutations (changes) in the cell's DNA, the part of the cell that contains its genes (blueprints). Sometimes this causes the cell to die, but sometimes it can lead to cancer later on. The amount of damage caused in the cell is related to the dose of radiation it receives. The damage takes place in only a fraction of a second, but other changes such as the beginning of cancer may take years to develop. (American Cancer Society, 2015, p. 1) 
Goetsch (2015) wrote that 21 workers from the Sellafield nuclear plant had died from causes related to ionizing radiation. One of the workers who had died from chronic myeloid leukemia was exposed to almost $52 \mathrm{mSv}$ of radiation over approximately nine months, a level that exceeded the established exposure limit for one year. The amount of ionizing radiation that the worker had been exposed to was much higher than the maximum allowable exposure limit of $1.25 \mathrm{Rems}$, which is $12.5 \mathrm{mSv}$ per calendar quarter. Additionally, younger workers are more susceptible to the adverse effects of radiation (American Cancer Society, 2015). Any worker likely to be exposed to radiation is to be monitored carefully, and radiation exposure must be limited to $50 \mathrm{mSv}$ in any single year, and $100 \mathrm{mSv}$ over five years (Goetsch, 2015).

\section{Risk Mitigation}

If a company finds that the EMF magnitude and frequency generated during eddy current and magnetic particle inspection exceeds the exposure limit values set by health and safety or regulatory authorities such as the UK HSE (2016) and UK Statutory Instruments (2016), they should immediately cease the work, conduct a risk assessment, and provide the appropriate health surveillance or medical examination. Workers should wear, and verify the effectiveness of, clothing and face/eye protection designed to shield EMF (Roh, Chi, Kang, \& Nam, 2008). Companies must ensure that EMF exposures remain within permissible levels before resuming eddy current and magnetic particle inspection activity.

The dye penetrant and developer chemicals are hazardous, and remain in use, together with the ultraviolet lamp used to illuminate the dye. To minimize worker exposure to the dye chemicals and ultraviolet light rays, the following protective measures are recommended:

- Isolate the dye penetrant inspection process location from the rest of the facility.

- Build a laminar flow fume hood with dilution and exhaust ventilation to contain the aircraft components and chemicals, to trap and remove the chemicals, and to add air in accordance with the dye penetrant manufacturer recommendations listed in the safety data sheet (SDS).

- Keep the aerosol exposure concentration below the minimum lethal air concentration and below the lethal dose (which defines the acute toxicity) of the hazardous dye ingredient specified in the SDS.

- Achieve verification with an aerosol monitor, estimating the chemical aerosol concentration via the molecular mass of the dye chemicals.

- Carry out the verification process periodically to confirm that the chemical aerosol removal is sufficient, and that the chemical concentration in the air is at an acceptable level. 
- Wear disposable body-covering clothing impervious to the dye chemicals, and ultraviolet ray-blocking eyeglasses.

- Point the ultraviolet lamp only towards the component being inspected, and away from the worker.

- If the component to be inspected needs to remain on the aircraft, wear a respirator with face shield and monitor the air quality. Dispose of all waste materials and clothing after dye penetrant and magnetic particle inspection in enclosed containers in accordance with regulatory requirements.

- Eyewash and emergency wash stations must be within easy reach in caseworkers are exposed to the dye chemicals by accident.

For X-ray and gamma-ray inspection, especially in cases in which the component being inspected is located externally, worker protection from radiation must be provided in the form of:

- Shielding such as lead sheets/plates/foil/clothing and barriers such as concrete.

- Personal radiation exposure levels using dosimeters for workers.

- Remote dosimeters installed at the hangar or workshop and following a radiographic inspection, workers must ensure that the radiation energy returns to background level before allowing anyone to walk around the area.

- The wireless radiographic image capturing and digitized data transfer technology to enable remote radiographic inspection.

Ultrasonic inspection utilizes high-frequency sound waves to detect surface and subsurface discontinuities in most metals, plastics, and laminated composites. The equipment generates acoustic waves that travel through the materials being examined, and are reflected in the material interfaces. The equipment transducers then receive the reflected signals, amplify them, and subsequently process and display them on the electronic oscilloscope screen for analysis. Modern test equipment generate low-energy acoustic waves within the radio frequency and ultrasound frequency range, with airframe and aircraft component inspections performed at up to $15 \mathrm{MHz}$ (Ansley et al., 1992; Fowler, Elfbaum, \& Nelligan, n.d.; Haase, W, \& Maurer, n.d.; Masserey, Raemy, \& Fromme, 2014; Smith, Bending, \& Jarman, 2002). Sound energy in the ultrasonic frequency range does not travel far through the air (Ansley et al., 1992), and ultrasonic noise on its own "has little effect on general health" (Occupational Safety \& Health Administration, n.d., p. 1) as long as there is no direct body contact with the material being excited by the ultrasonic source. Regardless, the American Conference of Governmental Industrial Hygienists (ACGIH) has established permissible ultrasound exposure levels to prevent possible hearing loss and reported cases of headache and nausea 
caused by the subharmonics of the ultrasound frequencies, rather than the ultrasonic wave itself. This includes the 8-hour time-weighted average limit values of 88-94 $\mathrm{dB}$ in the air, set at the middle frequencies of the one-third octave bands from 10 $\mathrm{kHz}$ to $50 \mathrm{kHz}$ (Occupational Safety \& Health Administration, n.d.). Therefore, workers should put on adequate ear protection before performing ultrasonic testing to minimize hearing loss.

In passive infrared thermography, infrared radiation emitted by an aircraft component is picked up by a camera containing infrared array detectors. Infrared cameras have evolved into very sensitive handheld devices that can capture, process and display the heat energy distribution within a component, in real-time, with very high resolution. Infrared cameras and computational thermography algorithms have been developed to detect the following (Bagavathiappan, Lahiri, Saravanan, Philip, \& Jayakumar, 2013):

- Metallic material undergoing plastic deformation from uniaxial tensile loading.

- Electrical and electronic component overheat conditions.

- Component failure forecasts from localized abnormal temperature rise.

- Porosities arising from compromised welding processes.

- Hidden corrosion damage - surface temperature variations associated with a loss of material identified subsurface corrosion areas (Grinzato \& Vavilov, 1998).

- Condition monitoring of large surface areas on the aircraft, including composite structures and materials. Saarimäki and Ylinen (2008) used a freezing and reheating procedure, and thermographic imaging to detect water that leaked into flight control structures made of composite honeycomb sandwich materials.

- Other aircraft inspection applications include temperature monitoring of electrical deicers on helicopter rotor blades, detection of cooling system blockages in jet engine turbine blades (Burleigh, 1994), and insulation defects in the cockpit.

The abovementioned examples together with the fact that infrared cameras now exist as sturdy, compact, handheld devices, support the contention that personnel should utilize passive infrared thermography to check aircraft component condition while it is still installed on-wing or on the flight line. Workers should take precautions avoid close proximity to components that remain hot from recent operations (e.g., brake discs, wheels, and tires on the landing gear assembly).

The use of eddy current, magnetic particles and dye penetrants to inspect aircraft components were heretofore perceived to be innocuous, and inspection 
procedures using these particular methods have been called out in aviation authority directives and component maintenance manuals. However, studies over the past 20 years have revealed that excessive exposure to EMF and dye chemicals have adverse health effects on workers. While the EU and UK are taking initiatives to restrict the use of dye chemicals containing carcinogens and limiting EMF exposure, aviation authorities in addition to aircraft and component manufacturers should emphasize and develop less hazardous inspection methods worldwide. Ultrasonic testing is much less hazardous, and passive infrared thermography technology poses no identified health hazards. Additionally, infrared thermography can be configured for further applications in the non-destructive inspection. Ultrasonic and passive thermographic methods should be prescribed as the preferred non-destructive inspection methods in the aviation industry and other industrial engineering fields to ensure the health as well as the safety of personnel. 


\section{References}

American Cancer Society. (2015). X-rays, gamma rays, and cancer risk. Retrieved from http://www.cancer.org/acs/groups/cid/documents/webcontent/acspc038756-pdf.pdf

Ansley, G., Bakanas, S., Castronuovo, M., Grant, T., \& Vichi, F. (1992). Current nondestructive inspection methods for aging aircraft (DOT/FAA/CT91/5). Retrieved from http://www.dtic.mil/dtic/tr/fulltext/u2/a256786.pdf

Bagavathiappan, S., Lahiri, B. B., Saravanan, T., Philip, J., \& Jayakumar, T. (2013). Infrared thermography for condition monitoring - a review. Infrared Physics \& Technology, 60, 35-55. doi:10.1016/j.infrared.2013.03.006

Burleigh, D. D. (1994). Infrared techniques in the aerospace industry. In X. P. V. Maldague (Ed.), Infrared Methodology and Technology (pp. 429-452). Amsterdam, Netherlands: Gordon and Breach Science Publishers.

Electric Power Research Institute. (2003). EPRI comments on the IEEE standard for safety levels with respect to human exposure to electromagnetic fields, 0 to $3 \mathrm{kHz}$ (2002). Retrieved from https://www.osha.gov/SLTC/elfradiation/epri-ieee1-03d.pdf

Federal Aviation Administration. (1998). Advisory circular 43-13.1B: Chapter 5. Nondestructive inspection (NDI). Retrieved from http://www.faa.gov/documentLibrary/media/Advisory_Circular/Chapter_0 5.pdf

Fowler, K. A., Elfbaum, G. M., \& Nelligan, T. J. (n.d.). Theory and application of precision ultrasonic thickness gaging. Retrieved from https://www.olympus-ims.com.cn/resources/white-papers/theory-andapplication-of-precious-ultrasonic-thickness-gaging/

García-Martín, J., Gómez-Gil, J., \& Vázquez-Sánchez, E. (2011). Non-destructive techniques based on eddy current testing. Sensors, 11(3), 2525-2565. doi:10.3390/s110302525

Goetsch, D. L. (2015). Occupational safety and health for technologists, engineers, and managers. (8th ed.). New York City, NY: Pearson Education Inc., 449-451. 
Golka, K., Kopps, S., Prager, H. M., Mende, S. V., Thiel, R., Jungmann, O., Zumbe, J., Hermann, M. B., Meinolf, B., Hengstler, J. G., \& Selinski, S. (2012). Bladder cancer in crack testers applying azo dye-based sprays to metal bodies. Journal of Toxicology and Environmental Health, Part A, 75, 566-571.

Grinzato, E., \& Vavilov, V. (1998). Corrosion evaluation by thermal image processing and 3D modelling. Revue Generale de Thermique, 37(8), 669679. Retrieved from https://tpu.pure.elsevier.com/en/publications/corrosion-evaluation-bythermal-image-processing-and-3d-modelling(20631e34-47a8-4a8e-a8c2aa09dd1b4c79).html

Haase, W., \& Maurer, A. (n.d.). Latest developments on industrial testing of aircraft components. Retrieved from http://www.ndt.net/article/wcndt2004/pdf/aerospace/371_haase.pdf

Lippert, J. F., Lacey, S. E., Kennedy, K. J., Esmen, N. A., Buchanich, J. M., \& Marsh, G. M. (2007). Magnetic field exposure in a nondestructive testing operation. Archives of Environmental \& Occupational Health, 62(4), 187193. doi:10.3200/AEOH.62.4.187-193

Masserey, B., Raemy, C., \& Fromme, P. (2014). High-frequency guided ultrasonic waves for hidden defect detection in multi-layered aircraft structures. Ultrasonics, 54(7), 1720-1728. doi:10.1016/j.ultras.2014.04.023

Noon, A. P., Pickvance, S. M., \& Catto, J. W. (2012). Occupational exposure to crack detection dye penetrants and the potential for bladder cancer. Occupational and Environmental Medicine, 69(4), 300-301. doi:10.1136/oemed-2011-100379

Occupational Safety \& Health Administration. (n.d). Noise and hearing conservation - Appendix I: D. Retrieved from https://www.osha.gov/dts/osta/otm/noise/health_effects/ultrasonics.html

Roh, J. S., Chi, Y. S., Kang, T. J., \& Nam, S. W. (2008). Electromagnetic shielding effectiveness of multifunctional metal composite fabrics. Textile Research Journal, 78(9), 825-835. doi:10.1177/0040517507089748

Saarimäki, E., \& Ylinen, P. (2008, July). An investigation of non-destructive thermographic inspection exploiting phase transition of water for moisture detection in aircraft structures. Paper presented at the 9th International Conference on Quantitative Infrared Thermography, Krakow, Poland. doi:10.21611/qirt.2008.12_08_16 
Smith, R. A., Bending, J. M., Jones, L. D., \& Jarman, T. R. C. (2002). Rapid ultrasonic inspection of ageing aircraft. Retrieved from http://www.ndts.com/files/1613/4496/0009/Rapid_Ultrasonic_Inspection_ of_Ageing_Aircraft_Full_Paper.pdf

United Kingdom Health and Safety Executive. (2016, July). Electromagnetic Fields at Work: A Guide to the Control of Electromagnetic Fields at Work Regulations 2016. Retrieved from http://www.hse.gov.uk/pubns/priced/hsg281.pdf

United Kingdom Statutory Instruments, 2016 No. 588, Health and Safety: The Control of Electromagnetic Fields at Work Regulations 2016. Retrieved from http://www.legislation.gov.uk/uksi/2016/588/pdfs/uksi_20160588_en.pdf

World Health Organization. (n.d.). About electromagnetic fields: 5. current standards. Retrieved from http://www.who.int/pehemf/about/WhatisEMF/en/index4.html 